\title{
MANAGING SPECIFIC FRESHWATER ECOSYSTEMS
}

A.H. Arthington ${ }^{1}$, C.M. Finlayson ${ }^{2}$, D.J. Roux ${ }^{3}$, J.L. $\mathrm{Nel}^{4}$, W. Rast ${ }^{5}$, R. Froend ${ }^{6}$, J. Turpie ${ }^{7}$, L. van Niekerk ${ }^{8}$

\author{
${ }^{1}$ Australian Rivers Institute, Griffith University, Brisbane, Queensland, Australia \\ ${ }^{2}$ Institute for Land, Water and Society, Charles Sturt University, Albury, Australia \& Institute \\ for Water Education, UNESCO-IHE, Delft, The Netherlands \\ ${ }^{3}$ South African National Parks \& Research Associate of the Sustainability Research Unit, \\ Nelson Mandela Metropolitan University, South Africa \\ ${ }^{4}$ Sustainability Research Unit, Nelson Mandela Metropolitan University, South Africa \\ ${ }^{5}$ International Watershed Studies, Meadows Center for Water and the Environment, Texas \\ State University, USA \\ ${ }^{6}$ Centre for Ecosystem Management, Edith Cowan University, Joondalup, Western Australia \\ ${ }^{7}$ Anchor Environmental Consultants \& Honorary Research Associate, South African Institute \\ for Aquatic Biodiversity \& Environmental Economics Policy Research Unit, University of \\ Cape Town, South Africa \\ ${ }^{8}$ Council for Scientific and Industrial Research and Nelson Mandela Metropolitan University, \\ South Africa
}

\section{Key Messages}

A number of relatively simple changes to the way PAs are designed and managed can help to further improve their conservation benefits for surface and ground water dependent freshwater ecosystems and estuaries. These include: avoid using a river as the boundary of a protected area; incorporate natural large-scale catchment processes into PAs; ensure that the water regimes of rivers, lakes, peatlands and groundwater-dependent ecosystems, as well as their linkages and interactions, are recognized and well managed within PAs and their catchments; avoid development of visitor infrastructure on priority freshwater ecosystems in PAs; encourage expansion of existing PAs to incorporate biodiversity hotspots, functional processes and connectivity; and promote new PAs for the last remaining free-flowing rivers and other high priority freshwater ecosystems.

PAs on their own are unlikely to fully protect freshwater ecosystems, especially where largescale catchment threats impinge on the protected area and its ecosystems. Therefore, conservation efforts should not stop at the boundaries of PAs, but extend into developing cooperative relationships and activities among various entities with overlapping water 
management mandates. Integrated and adaptive management approaches that facilitate engagement and empowerment of all stakeholders, inclusive and iterative learning, and purposeful action amidst inherent complexities, are recommended.

Establishing environmental flows and maintaining the water regimes of rivers, lakes and GDEs are critical for sustaining biodiversity and ecosystem services inside freshwater and estuarine PAs. Conservation managers should aim to ensure that the natural water regimes of specific freshwater ecosystems are protected. Setting a limit on hydrologic alteration remains the most challenging aspect of implementing environmental flows, although methods and guidelines are available to assist in this task.

Effective management of GDEs requires integration of associated surface and groundwater resources and necessitates an understanding of the origins, pathways and storages of water. Some GDEs are entirely dependent on continuous groundwater discharges, whilst others are maintained by minor but critical groundwater inflows restricted to particular seasons or inter-annual episodes.

The International Lake Environment Committee (ILEC 2005) has identified six major pillars for lake governance: 1) policies, which represent the "rules of the game"; 2) institutions, representing the entities responsible for carrying out the rules of the game; 3) stakeholder participation in implementing effective management plans; 4) technology, involving selection of "hard" versus "soft" management approaches; 5) knowledge and information, focusing on obtaining the most accurate information and data; and (6) finances, including identifying and ensuring sustainable sources. These pillars are encompassed within the concept of Integrated Lake Basin Management (ILBM), which represents a major complement to Integrated Water Resources Management (IWRM) for addressing lakes, reservoirs, wetlands and other lentic water systems.

\section{Freshwater ecosystems in protected areas}

Relatively few PAs have been established specifically to protect freshwater habitats and biota. The norm is for terrestrial biodiversity features to drive the design of PAs with the inclusion of freshwater features being a secondary or neglected consideration (Abell et al, 2007; Allan et al, 2010; Herbert et al, 2010). As an example, the iconic Kruger National Park in South Africa was proclaimed in 1926 in the north-eastern corner of the country as a last local refuge for large savannah mammals. The use of modern-day conservation planning 
tools shows that Kruger's inherited design (as a belt of land across the middle of five river catchments) caters poorly for freshwater conservation, both in terms of representing the diversity of freshwater features in the associated eco-region and supporting persistence of those features (Roux et al, 2008). By contrast, Kakadu National Park in Australia largely incorporates the catchments of two major rivers from their watersheds to the sea.

Notwithstanding their terrestrial bias, PAs do extend critical protection to freshwater systems; for example, the ecological state of rivers in formally declared PAs of South Africa is significantly better than of their counterparts outside PAs (Nel et al, 2007). A number of relatively simple changes to the way PAs are designed or expanded can help to further improve their conservation benefits for freshwater ecosystems, namely to: avoid using a river as the boundary of a protected area; encourage expansion of existing PAs to incorporate natural large-scale catchment processes into PAs where possible; ensure that the water regimes of rivers, lakes, peatlands and groundwater-dependent ecosystems are well managed within Pas and their catchments, enabling them to recover from the impact of activities upstream as they flow through the protected area; avoid development of visitor infrastructure on priority freshwater ecosystems in PAs; encourage expansion of existing PAs to incorporate biodiversity hotspots, functional processes and connectivity pathways at relevant scales; and promote new PAs for the last remaining free-flowing rivers and other high priority freshwater ecosystems (Nel et al, 2009).

No matter how considerate their designs, PAs on their own are unlikely to ever fully protect freshwater ecosystems because of their connected nature across longitudinal and lateral drainage lines spanning large-scale landscapes (Dudgeon et al, 2006). Therefore, conservation efforts should not stop at the boundaries of PAs but extend into developing cooperative relationships among various entities with overlapping water management mandates, including policy sectors for water, biodiversity, land-use planning and agriculture at catchment scale. Indeed, PAs can be powerful catalysts for freshwater ecosystem management outside their boundaries (Pollard et al, 2003). Ultimately, different legislative frameworks and place-based mechanisms (Abell et al, 2007; Allan et al, 2010) need to work in better harmony to enable integrated management of rivers at basin scales and bring effective freshwater conservation strategies to bear. Moreover, active cooperation across all levels and spheres of government is required to arrest the main threats to global freshwater biodiversity, notably overexploitation, water pollution, flow modification, destruction or 
degradation of habitat, invasion by alien species, and increasingly, climate change (Dudgeon et al, 2006; Pittock et al., 2017).

The dual imperative of having to cooperate with multiple management agencies and stakeholders, and deal with multiple interacting and constantly changing threats (with uncertain and contested outcomes) add both a social and a biophysical layer of complexity to the task of conserving freshwaters. Under these circumstances, adaptive management seems to be gaining traction as an approach to management. Such an approach essentially enables a process of social learning among scientists, managers and stakeholders (Pahl-Wostl et al, 2007), leading towards a shared understanding of issues, consensus around a vision of the desired state of a catchment (Arthington, 2012) and a hierarchy of objectives that connects the high-level vision with measurable and implementable end points (McLoughlin et al, 2015). Through engagement and empowerment of stakeholders, as well as inclusive and iterative learning, adaptive management facilitates purposeful action amidst inherent complexities and uncertainties (Kingsford et al, 2011a; Pollard et al, 2011). In Australia the water plan for the Murray-Darling Basin is built around an adaptive management framework with five year reviews of the environmental watering, water quality and salinity management plans, and after 10 years a review of the overall plan (Neave et al, 2015; Swirepik et al, 2015). It is intended that these reviews will be informed by the assessment of sub-Basin water resource plans, monitoring and evaluation of environmental flow outcomes, and investigations of the impacts of climate change. The efficacy of such measures has yet to be tested with concerns about overly narrow or mal-adapted perspectives that could reduce the resilience of the freshwater ecosystems (e.g. Pittock and Finlayson, 2013). A major concern is the reliance on engineering works and measures rather than the adoption of ecosystembased measures to maintain a more diverse range of ecological processes that would spread the risks and conserve a more diverse range of biota.

While the connected nature of freshwater systems poses challenges to conservation through PAs, it also presents opportunities to reimagine and reframe the role of PAs in society. Ecologically intact ecosystems such as wetlands and rivers provide many essential services with benefit pathways extending well beyond PA boundaries (Palomo et al, 2014). Waterbased ecosystem services include water provision and increased water security to downstream users (Harrison et al, 2016), fisheries and other food resources, regulating services such as filtering pollutants from water, regulating flows and contributing to erosion 
control, and cultural services such as new knowledge generation through research, opportunities for education, sense of place, recreation opportunities and tourism. In a PA context, an ecosystem services approach can help to link conservation objectives with social, economic and cultural values of ecosystems (Martín-López et al., 2014; Boerema et al., 2016) and to contextualise the contribution of PAs to human well-being within their larger socialecological landscapes (Palomo et al., 2014; García-Llorente et al., 2016). This broader justification of PAs is increasingly deemed necessary (Watson et al, 2014; Cumming, 2016).

Notwithstanding that wetlands and rivers are among the most threatened ecosystems in the world (Millennium Ecosystem Assessment, 2005; Dudgeon et al, 2006; Vörösmarty et al, 2010), reporting on the performance of protected areas in achieving global conservation targets commonly concentrates on terrestrial and marine ecosystems only (Watson et al, 2014; Butchart et al, 2015). The absence of freshwater indicators in these performance assessments is at least in part due to the complex nature of freshwater conservation, as outlined above and in the ecosystem sections below. While the sum of protected hectares may serve as a proxy for the achievement of terrestrial and marine conservation targets, rivers that flow through protected areas are typically not in an ecologically intact condition due to disturbance of upstream and downstream connectivity pathways and threats beyond PA boundaries (Arthington et al., 2017). Indicators to measure the ecological condition of freshwater ecosystems in PAs need to reflect the true protection status of these systems (Nel et al., 2007). The EU Water Framework Directive targets for 'good ecological status' in all surface waters provide one example of attempts to define rigorous condition assessments at a continental scale. (Finlayson et al, 2017). Indicators of protection status and ecological condition would also link directly to the capacity of freshwater ecosystems to provide ecosystem services (Brauman et al., 2007), which in turn relate to the achievement of both Aichi conservation targets and the UN Sustainable Development Goals (Osborne et al., 2015).

\section{Rivers, environmental flows and wetland water regimes}

\section{Rivers and flow regimes}

Rivers and lakes hold $100,000 \mathrm{~km}^{3}$ of fresh water and groundwater holds about 15,000 km much of it stored in deep aquifers not in active exchange with the earth's surface (Jackson et al, 2001). The world's largest river systems comprise $60 \%$ of the world's river runoff. 
Flowing or 'lotic' surface waters are prominent features of most landscapes, even deserts, and they exert a significant influence on landscape form and function. Rivers are the major agents of erosion, transport and deposition of materials from the mountains to valleys, to inland wetlands and lakes, and to estuaries and the oceans. Their biotic communities reflect a long evolutionary history of adaptations to dynamic, heterogeneous environments and the biological processes of competition, predation, colonization, succession and extinction. Fresh waters in rivers and their floodplain wetlands support ecosystems with diverse life forms and biogeochemical processes that provide ecological and cultural goods and services of critical importance to human societies (MEA, 2005). These goods and services are increasingly threatened by human activities in rivers and their catchments through over-exploitation of water and biological resources (e.g. fish), water pollution, fragmentation and destruction of habitat, invasion by alien species, and climate change (Dudgeon et al, 2006). All of these threatening processes are linked and exacerbated through the modification of river flows and wetland inundation regimes. Land-use change, river impoundment, surface and groundwater abstraction and artificial inter/intra-basin transfers of water are the major drivers of change in water regimes. However, dams have the most impact on rivers and aquatic biodiversity by altering river flows, sediment dynamics, water quality and water temperatures, degrading habitats and blocking species movement. As discussed further in the section on lakes, they also exhibit a buffering function in regard to pollutant and other inputs, therefore potentially masking upstream degradation in a drainage basin assessed at its downstream end. On a global scale, there are 945,000 dams above $15 \mathrm{~m}$ high, capable of holding back $96,500 \mathrm{~km}^{3}$ of water or about $15 \%$ of the total annual river runoff globally. Thousands more are proposed, particularly in developing countries wishing to enhance 'green' energy supplies by means of hydropower developments (Winemiller et al, 2016).

Threats to rivers and freshwater biodiversity are increasing in many regions as human populations expand and seek higher living standards and improved quality of life (Vörösmarty et al., 2010). Paradoxically, the increasing modification of rivers and their flow regimes will rarely bring benefits to millions of people who depend on river resources for livelihoods, health and well-being (e.g. in the Mekong river system). Protected areas offer a powerful means to conserve species-rich habitats and vital resources, important species radiations, aquatic biodiversity and ecosystem services, cultural values and belief systems. To be most effective, freshwater PAs should have control over the upstream drainage network, the surrounding land, the riparian zone, and downstream reaches (Dudgeon et al, 2006), and 
maintain both connectivity pathways and habitat patchiness. At the very least, within PAs, the goal should be to protect the natural water regimes of rivers, wetlands and floodplains from over-use, diversion and impoundment.

\section{Environmental Flows}

Freshwater management has been integrated into the broader scope of ecological sustainability through the provision of environmental flows, defined as (Brisabane Declaration, 2007):

"the quantity, timing and quality of water flows required to sustain freshwater and estuarine ecosystems and the human livelihoods and well-being that depend upon these ecosystems"

There is now wide recognition that a dynamic, variable water regime is required to maintain species phenology (seasonal timing of events in the life cycle) and the native biodiversity and ecological processes characteristic of every river and wetland ecosystem (Poff et al, 1997). The natural flow regime paradigm and diverse eco-hydrological principles (e.g. Bunn and Arthington, 2002) flesh out the influence of flow volume, seasonal timing and variability on aquatic habitats, biodiversity, population recruitment and ecosystem productivity. These ecohydrological principles inform assessment of the environmental flow requirements of aquatic and riparian plants, invertebrates, fish, waterbirds and other water-dependent animals (e.g. frogs, snakes and lizards, beavers and platypus). Other principles elaborate water-related ecosystem characteristics and processes such as foodweb structure, energy flow and biological interactions.

The key challenge for management where PAs receive water from unreserved upstream catchments is to engage water managers and users in a collaborative process for envisioning, assessing, implementing and monitoring environmental flows.

Over 250 practical methods, models and frameworks have been developed to link water volumes and patterns of flow to biodiversity and ecological processes, and thereby to define the environmental flow requirements of rivers and streams (Dyson et al, 2003; Tharme, 2003). While environmental flow assessment may seem complex, a simple guide to the main technical options available for protected area managers to assess what is required is given in Table 8.1. These methods focus largely on rivers and streams. However, they are applicable in concept and practice to lakes, ponds and wetlands that rarely flow but nevertheless experience natural spatial and seasonal patterns of water level fluctuation, wetting and drying, 
and hydrological links to rivers and groundwater. Estuaries also need to receive freshwater inflows to maintain their salinity regime, biodiversity, fisheries productivity and amenity values (see estuaries section below). Water regime assessment methods and applications for rivers, wetlands, groundwater-dependent ecosystems and estuaries can be found in Arthington (2012) and references therein.

Table 8.1: Environmental flow methods. Comparison of the four main types of methods used worldwide to estimate environmental flows = environmental water allocations - EWA (adapted from Tharme, 2003), for examples see Arthington, 2012). Resource intensity is represented in terms of time, cost and technical capacity.

\begin{tabular}{|c|c|c|c|c|}
\hline Type & $\begin{array}{l}\text { River ecosystem } \\
\text { components }\end{array}$ & $\begin{array}{l}\text { Data } \\
\text { requirements } \\
\text { and resource } \\
\text { intensity }\end{array}$ & $\begin{array}{l}\text { Resolution of } \\
\text { output } \\
\text { (EWA) }\end{array}$ & $\begin{array}{l}\text { Appropriate } \\
\text { levels of } \\
\text { application }\end{array}$ \\
\hline Hydrological & $\begin{array}{l}\text { Whole ecosystem, } \\
\text { non-specific, or } \\
\text { only some biota } \\
\text { (e.g. Montana } \\
\text { method, Tennant, } \\
\text { 1976) }\end{array}$ & $\begin{array}{l}\text { Low } \\
\text { Primarily } \\
\text { desktop } \\
\text { Use naturalised } \\
\text { historical flow } \\
\text { records } \\
\text { Some use } \\
\text { historical } \\
\text { ecological data }\end{array}$ & $\begin{array}{l}\text { Low } \\
\text { Expressed as } \\
\% \text { of monthly } \\
\text { or annual flow } \\
\text { (median or } \\
\text { mean); or as } \\
\text { limits to } \\
\text { change in flow } \\
\text { parameters } \\
\text { (e.g. Range of } \\
\text { Variability } \\
\text { Approach = } \\
\text { RVA, Richter } \\
\text { et al, 1996). }\end{array}$ & $\begin{array}{l}\text { Reconnaissance } \\
\text { level of water } \\
\text { resource } \\
\text { developments, or } \\
\text { as a tool within } \\
\text { habitat } \\
\text { simulation or } \\
\text { holistic } \\
\text { (ecosystem) } \\
\text { methodologies } \\
\text { Used widely }\end{array}$ \\
\hline $\begin{array}{l}\text { Hydraulic } \\
\text { rating }\end{array}$ & $\begin{array}{l}\text { In-stream habitat } \\
\text { for target biota }\end{array}$ & $\begin{array}{l}\text { Low-medium } \\
\text { Desktop or } \\
\text { limited field } \\
\text { work } \\
\text { Historical flow } \\
\text { records } \\
\text { Discharge } \\
\text { linked to } \\
\text { hydraulic } \\
\text { variables - } \\
\text { typically at } \\
\text { single river } \\
\text { cross-section }\end{array}$ & $\begin{array}{l}\text { Low-medium. } \\
\text { Hydraulic } \\
\text { variables (e.g. } \\
\text { wetted } \\
\text { perimeter) } \\
\text { used as } \\
\text { surrogate for } \\
\text { habitat-flow } \\
\text { needs of target } \\
\text { species or } \\
\text { assemblages }\end{array}$ & $\begin{array}{l}\text { Water resource } \\
\text { developments } \\
\text { where little } \\
\text { negotiation is } \\
\text { involved, or as a } \\
\text { tool within } \\
\text { habitat } \\
\text { simulation or } \\
\text { holistic } \\
\text { (ecosystem) } \\
\text { methodologies } \\
\text { Used widely }\end{array}$ \\
\hline
\end{tabular}




\begin{tabular}{|c|c|c|c|}
\hline $\begin{array}{l}\text { Habitat } \\
\text { simulation }\end{array}$ & $\begin{array}{l}\text { Primarily in-stream } \\
\text { habitat for target } \\
\text { biota } \\
\text { Some consider } \\
\text { channel form, } \\
\text { sediment transport, } \\
\text { water quality, } \\
\text { riparian vegetation, } \\
\text { wildlife, recreation } \\
\text { and aesthetics (e.g. } \\
\text { PHABSIM, Bovee, } \\
\text { 1982) }\end{array}$ & $\begin{array}{l}\text { Medium - high } \\
\text { Desktop and } \\
\text { field } \\
\text { Historical flow } \\
\text { records. Many } \\
\text { hydraulic } \\
\text { variables are } \\
\text { modelled at } \\
\text { range of } \\
\text { discharge at } \\
\text { multiple stream } \\
\text { cross-sections } \\
\text { Use physical } \\
\text { habitat } \\
\text { suitability or } \\
\text { preference of } \\
\text { target species }\end{array}$ & $\begin{array}{l}\text { Medium - } \\
\text { high } \\
\text { Output in form } \\
\text { of Weighted } \\
\text { Useable Area } \\
\text { (WUA) of } \\
\text { habitat for } \\
\text { target species } \\
\text { (fish, inverts, } \\
\text { plants). May } \\
\text { involve time- } \\
\text { series of } \\
\text { habitat } \\
\text { availability }\end{array}$ \\
\hline
\end{tabular}

Water resource developments, involving rivers of high strategic importance, often with complex, negotiated tradeoffs among users, or as method within holistic (ecosystem) approaches Primarily used in developed countries

\begin{tabular}{|c|c|c|c|c|}
\hline $\begin{array}{l}\text { Holistic } \\
\text { (ecosystem } \\
\text { frameworks }\end{array}$ & $\begin{array}{l}\text { Whole ecosystem, } \\
\text { all or several } \\
\text { ecological } \\
\text { components } \\
\text { Most consider in- } \\
\text { stream and riparian } \\
\text { biota, some also } \\
\text { consider: } \\
\text { groundwater, } \\
\text { wetlands, } \\
\text { floodplains, } \\
\text { estuary and coastal } \\
\text { waters } \\
\text { May assess social } \\
\text { and economic } \\
\text { dependence on } \\
\text { species/ecosystem } \\
\text { (e.g. DRIFT, King } \\
\text { et al, 2003) }\end{array}$ & $\begin{array}{l}\text { Medium - high } \\
\text { Desktop and } \\
\text { field } \\
\text { Use naturalized } \\
\text { flow records or } \\
\text { rainfall records } \\
\text { cf. current } \\
\text { gauge records } \\
\text { Many hydraulic } \\
\text { variables at } \\
\text { multiple cross- } \\
\text { sections and } \\
\text { river sites } \\
\text { Biological data } \\
\text { on flow- and } \\
\text { habitat-related } \\
\text { requirements of } \\
\text { biota and } \\
\text { several } \\
\text { ecological } \\
\text { components }\end{array}$ & $\begin{array}{l}\text { Medium - } \\
\text { high } \\
\text { Fish methods } \\
\text { consider } \\
\text { movement and } \\
\text { migration, } \\
\text { requirements } \\
\text { for spawning, } \\
\text { all life stages; } \\
\text { water quality } \\
\text { tolerances; } \\
\text { exotic species } \\
\text { included (e.g. } \\
\text { DRIFT } \\
\text { Arthington et } \\
\text { al, 2003) } \\
\text { ELOHA } \\
\text { quantifies e- } \\
\text { flow 'rules' for } \\
\text { rivers of } \\
\text { contrasting } \\
\text { hydrological } \\
\text { type at basin } \\
\text { and regional } \\
\text { scale (Poff et } \\
\text { al, 2010) }\end{array}$ & $\begin{array}{l}\text { Water resource } \\
\text { developments, } \\
\text { typically large- } \\
\text { scale, involving } \\
\text { rivers of high } \\
\text { conservation } \\
\text { value or strategic } \\
\text { importance, } \\
\text { and/or with } \\
\text { complex user } \\
\text { trade-offs } \\
\text { Expert panels } \\
\text { often used where } \\
\text { flow-ecology } \\
\text { knowledge is } \\
\text { limited, or there } \\
\text { are limited trade- } \\
\text { offs among users, } \\
\text { and/or time } \\
\text { constraints. } \\
\text { Used in } \\
\text { developing and } \\
\text { developed } \\
\text { countries }\end{array}$ \\
\hline
\end{tabular}




\section{Setting limits to hydrological alteration}

Protecting a river's flow regime and other drivers should be a major goal of river conservation and PA management. Legitimate activities that can interfere with the natural flow regimes of rivers within a protected area may include water storage to support park ranger facilities and tourism infrastructure, the barriers formed by roads and bridges, and water extraction or diversion to maintain habitats and park flora and fauna. Furthermore, in numerous cases, the protected area may not incorporate the entire catchment supplying its water resources. For example, the upper tributaries of the Kruger National Park in South Africa flow through developed catchments (Roux et al, 2008).

Setting environmental flow targets for biodiversity and ecosystem conservation in PAs and other high value aquatic systems has challenged scientists and water managers to define how much change in vital attributes of natural flow regimes is acceptable. In spite of tremendous advances in methods, setting a limit on hydrologic alteration remains the most challenging aspect of environmental flow science and sustainable water management. Simple methods set this limit as a percentage of the mean natural annual or seasonal flow, whereas methods such as PHABSIM estimate the river discharge that maintains fish habitat and connectivity though a valued river reach or the channel network (Table 8.1). Holistic environmental flow frameworks have been particularly effective in formulating scenarios of possible ecological impact and risk arising from alterations to river flow regimes. In the holistic DRIFT and ELOHA frameworks (Table 8.1), and several restoration protocols (e.g. Poff et al, 2003; Richter et al, 2006), scientists, stakeholders and managers consider a suite of relationships between flow regime alterations and ecological changes for the rivers under study. An important concept is the idea of a critical threshold of hydrological change above or below which ecological functions or elements of the ecosystem are impaired or lost (Arthington et al, 2006). These threshold discharges may include sufficient high flow to connect the river with its riparian corridor or floodplain, or to move sediment, or sufficient low flow to maintain within-channel connectivity between shallow (e.g., riffle) areas, and promote oxygenation of stream habitats. Some of the greatest successes in environmental flow management have seen close collaboration of scientists, water managers, community groups and farmers, for example, in preparing the Murray-Darling Basin Plan (Commonwealth of Australia, 2012). 


\section{Adapting to climate change}

The natural environmental regimes that govern aquatic ecosystems, especially water regimes, have been replaced by altered regimes in many areas of the world under increasing human pressure for fresh water and in response to shifting climates (see IPCC, 2007). The combination of climate change and flow regulation is now driving structurally novel ecosystems that may require new thinking and a range of approaches to water management to cope with increasingly uncertain futures (Palmer et al, 2008). Research that identifies flow regime characteristics and associated ecological responses to variability by quantitative methods and models is one of the best options for preparedness. The study of ecological responses along contemporary gradients of flow variability (wet to dry tropics, coastal to arid-zone regions) may provide analogues for future climatic shifts (Arthington et al, 2006). Another approach is the application of models that make use of empirical data and expert judgements to compare and contrast scenarios of water use or climate change (e.g. Chan et al, 2012). An important way to advance understanding of the ecological roles of flow, and to improve water use for ecosystem and human benefit, is through well-designed monitoring of ecological outcomes over time in river systems receiving an environmental flow (Arthington, 2012; Davies et al, 2014).

\section{Guiding principles for environmental flows}

As implementation of environmental flows becomes accepted international best practice, protected area managers can take the lead in applying these concepts and methods to the diverse PAs and conservation systems they manage. Common, guiding steps in the different environmental flow methods outlined above include:

- Consult stakeholders to identify the different, flow-related elements of the environment that are valued (such as water quality, the riparian corridor and fish migrations) and collaboratively set environmental flow objectives;

- Describe flow-ecology relationships quantitatively, as the thresholds for water quality, volume and timing of flows needed to sustain the identified values. These flow-ecology relationships must inform the stakeholder values and the agreed environmental flow objectives;

- Identify the spatial and temporal scale of the environmental flows assessment and decide which specific methods and tools (Table 8.1) can best be applied (e.g. river reach, tributary, main large river channel, several rivers or basins); 
- Consider the natural seasonal variability of river flows and wetland water regimes, and seek opportunities to mimic these patterns as much as possible, for instance, with restrictions on water diversions or managed water releases from dams;

- Negotiate agreements with water agencies and other stakeholders to implement the environmental flows, including water departments and utilities; and

- Monitor and evaluate the ecological and social outcomes, and adjust the environmental flows to achieve the desired environmental and social objectives.

Environmental flows and water regimes are relevant to the conservation and management of lakes, peatlands, groundwater-dependent ecosystems and estuaries, as described in the next sections (see also Arthington, 2012).

\section{Lake conservation and management}

\section{Lakes}

Lakes are among the most dramatic, sometimes even mystical, features of our global landscape. There are an estimated 27 million natural lakes greater than one hectare in area. Indeed, the 17 largest lakes on the planet cover an area of approximately one million square kilometres. An estimated additional half million artificial lakes (reservoirs) with surface areas greater than one hectare add to this total. These water systems collectively contain more than $90 \%$ of the liquid freshwater on the surface of our planet at any given instant. It is estimated, for example, that the North American Great Lakes and Lake Baikal in the Russian Federation together contain approximately $38 \%$ of all this freshwater. In fact, lakes and reservoirs collectively provide a wider range of ecosystem goods and services than other aquatic ecosystems.

The Millennium Ecosystem Assessment (MEA, 2005) define ecosystem goods and services as benefits humans derive from ecosystems, including domestic, agricultural and industrial water supply, fisheries, recreation, tourism, hydropower generation, and transportation. In addition to providing habitat for a diverse plethora of aquatic species, lakes provide fundamental regulating services to humanity, including waste assimilation, climate, water and erosion regulation, water purification and refugia. They also have significant religious or cultural meanings for some societies.

Against this background, lakes (and all surface freshwater systems) can be characterized as being finite, in that the vast majority of our planet's fixed quantity of liquid freshwater 
resides in lakes and reservoirs; sensitive, in that lakes and reservoirs are easily polluted and degraded; and irreplaceable, in that there is no substitute for freshwater in its many uses (Illueca and Rast, 1996). In spite of their obvious importance, however, the unfortunate reality is that many lakes and reservoirs are being degraded at an accelerating rate, due mainly to a growing global population and associated agricultural and economic development activities, as well as the hydrologic impacts of a changing global climate.

The term 'lakes' is henceforth used to refer to both natural lakes and artificial reservoirs, noting that the biodiversity values of artificial lakes is generally lower than for natural ones. Noting that much of humanity's readily accessible liquid freshwater exists in lakes, managing these water bodies for their conservation is a complex undertaking involving a range of scientific, socioeconomic and governance elements. Further, rather than being isolated water bodies, lakes are hydrologically linked to upstream rivers or tributaries flowing into them, to downstream water systems into which they discharge, and sometimes also to sub-surface groundwater aquifers (Figure 8.1).

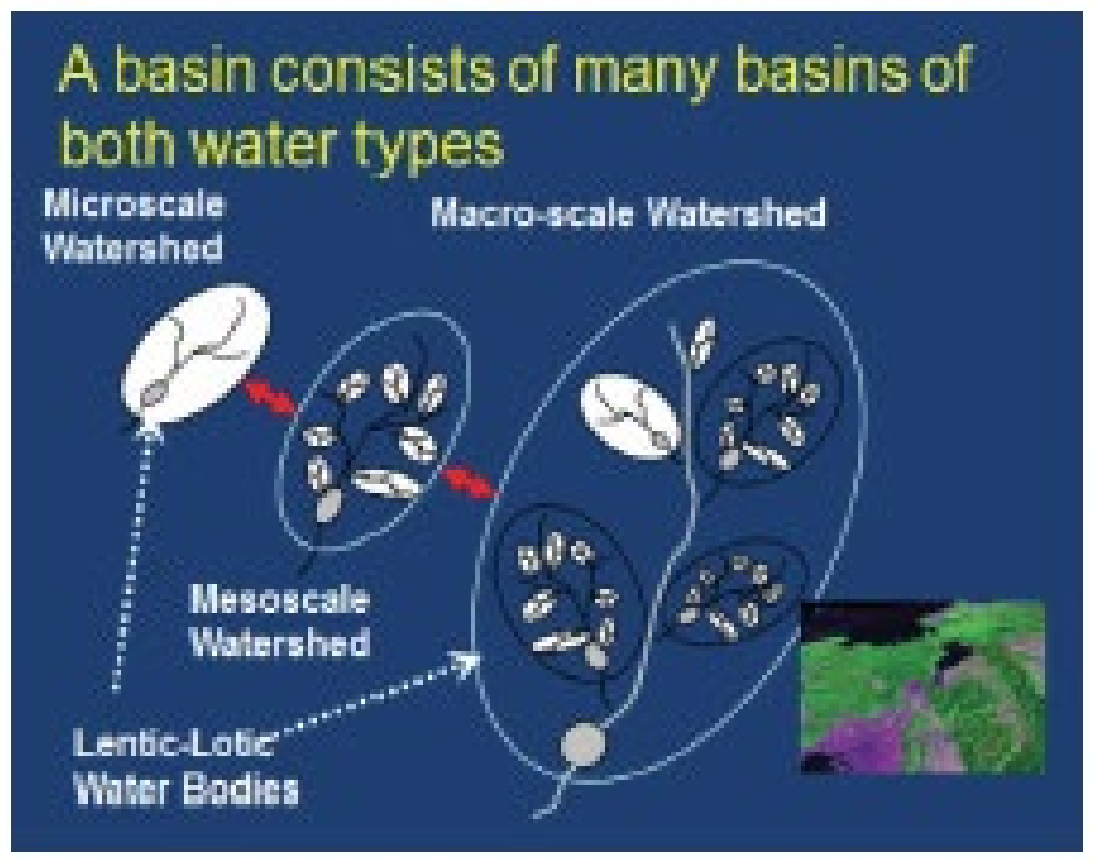

Figure 8.1: Links Between Water Basins at Different Scales and of Different Types in a Drainage Basin (modified from Nakamura and Rast, 2011). Figure used with permission of the International Lake Environment Committee, ILEC.

Lakes and reservoirs, as well as ponds, wetlands and estuaries, are 'lentic' water systems that pool or store freshwater. As such, they represent an expression of the ecological and 
anthropogenic state of water, with evolutionary and historic memories of human-nature interaction. This is certainly the case for many ancient lakes, examples being Biwa, Baikal, Issyk-Kul, Lanao, Malawi, Maracaibo, Prespa, Tanganyika, and Titicaca. This lentic characteristic is in contrast to 'lotic' water systems such as rivers and streams, characterized by flowing waters, thereby being the expression of the physical state and dynamics of water. The hydrologic linkages between these lentic and lotic water systems have important scientific and management implications. Downstream water needs, for example, can sometimes significantly dictate the management requirements of upstream lakes that supply water to them, an example being the Lake Biwa-Yodo River complex in Japan (Nakamura et al, 2012).

\section{Lake ecology}

The ecology and limnology of lakes is a major branch of aquatic science. In addition to providing the above-noted ecosystem goods and services, lakes also provide habitats for multiple, interacting aquatic organisms and communities, ranging from microscopic freefloating phytoplankton and zooplankton, to fish and aquatic mammals. The topic of aquatic science, however, cannot be comprehensively discussed within the context of this short overview. Useful sources for further discussion of lake and reservoir limnology include the works of Rast and Straskraba (2000), Wetzel (2001), Kalff (2002), O’Sullivan and Reynolds (2004), Dodson (2005) and Jorgensen et al. (2005).

In contrast to the strictly scientific concerns, lake conservation management essentially represents managing lakes for sustainable use. This translates into managing lakes, their basins and their resources for sustainable ecosystem services, whether these services are provisioning, regulating, cultural or supporting in nature (MEA, 2005). Managing lakes for conservation purposes involves a range of scientific/technical and socioeconomic/governance elements. The former include consideration of the quantity and quality of surface and groundwater sources, drainage basin characteristics, flora and fauna, soils, topography and land use, climate, etc., all of which collectively define the physical presence and condition of lake waters, including quality, quantity, condition, trends, stresses, etc. The latter include the legal and institutional framework within a lake drainage basin, economic considerations, demography, cultural and social customs, stakeholder participation possibilities, political realities, etc. The latter arguably comprise the most important elements in this regard, in that they fundamentally define the factors controlling how humans use their water resources, 
including lakes, their basins and their resources (GWP, 2000; Solanes and GonzalesVillarreal, 1999).

Effectively managing lakes for conservation and sustainability also requires recognition of three unique features characterizing these and other lentic water systems. As previously noted, these include an integrating nature; long water retention time; and complex response dynamics (ILEC, 2005). Because of their location at the hub of a drainage basin, lakes comprise the flow-regime integrators within the entire lake-river basin complex. The integrating nature of a lake refers to its function essentially as a 'mixing pot' for everything entering it from its surrounding drainage basin, and sometimes even from beyond its basin via the long range transport of airborne pollutants. This integrating nature transcends the entire lake and riparian land interfaces, thereby causing both the lake resources and the problems associated with them to form a complex web of cause-effect relationships propagating throughout the lake. Simply stated, lake stresses come from many sources, with everything coming together in the lake, making the issues mostly inseparable. The long water retention time refers to the average time water spends in a given lake. Long water retention times typically result from large water volumes, giving lakes a buffering capacity against materials entering them via inflowing waters, often without exhibiting immediate negative impacts. Thus, lake problems develop gradually, and may not become evident until they have become serious lake-wide problems that can significantly impact human water uses and ecosystem integrity. This same buffering trait also can produce a 'lag' phenomenon in response to remedial programs implemented to restore them, sometimes for decades or longer. In other words, while problems may take a long time to become evident, solutions to these problems also may take a long time to become evident. The complex response dynamics means lakes do not respond to perturbations or pollution in a linear manner, but rather exhibit hysteresis in response to these disturbances. Thus, problems are often unpredictable and uncontrollable. In fact, all lake problems are essentially lake-wide problems, with lakes experiencing serious degradation, including to the aquatic communities for which they provide habitats, typically not returning to the condition they exhibited prior to the degradation (Nakamura and Rast, 2011).

\section{Integrated lake basin management}

Against this backdrop, the underlying cause of nearly all lake and other aquatic ecosystem degradation or overexploitation is inadequate governance. In focusing on aquatic ecosystem 
provisioning and cultural services, governance inadequacies ensure that individuals, organizations and communities can readily overwhelm the ecosystem regulating and support services upon which these former services are directly dependent. The result can be a feedback that can ultimately degrade all these ecosystem services. Based on examining lake management experiences around the world, the International Lake Environment Committee (2005) has identified six major lake governance pillars requiring recognition and consideration. These include: (1) policies, which essentially represent the "rules of the game"; (2) institutions, representing the entities responsible for carrying out the rules of the game; (3) stakeholder participation, meaning the meaningful involvement of all relevant stakeholders in implementing effective management plans; (4) technology, involving selection of hard (constructions) versus soft (behavioural changes) management approaches; (5) knowledge and information, focusing on obtaining the most accurate information and data, which can comprise both scientific studies and indigenous knowledge; and (6) finances, including identifying and ensuring sustainable sources of adequate financial support. These six pillars comprise the essential governance elements that collectively form the management regime for an integrated approach to managing lakes and their basins, and which are directed to ensuring sustainable lake ecosystem services, as discussed in detail by Nakamura and Rast (2011). Lake Chilwa in Malawi (see Box 8.1) highlights these challenges.

\section{Box 8.1: Lake Chilwa, Malawi}

Lake Chilwa covers approximately $2284 \mathrm{~km}^{2}$ and is located in the south of Malawi and along the border with Mozambique (Figure 8.3).

It is a shallow, enclosed endorheic saline lake with an average depth of $1-2 \mathrm{~m}$, and is surrounded by an area of marsh dominated by dense stands of Typha with a seasonally inundated floodplain (Rebelo et al, 2011). The catchment covers $8,784 \mathrm{~km}^{2}$, with $5,724 \mathrm{~km}^{2}$ in Malawi and 3,060 $\mathrm{km}^{2}$ in Mozambique. The annual rainfall across the catchment is approximately $1,362 \mathrm{~mm}$, with water levels in the lake fluctuating three to four metres seasonally. These seasonal variations are superimposed on longer wetting and drying cycles, 


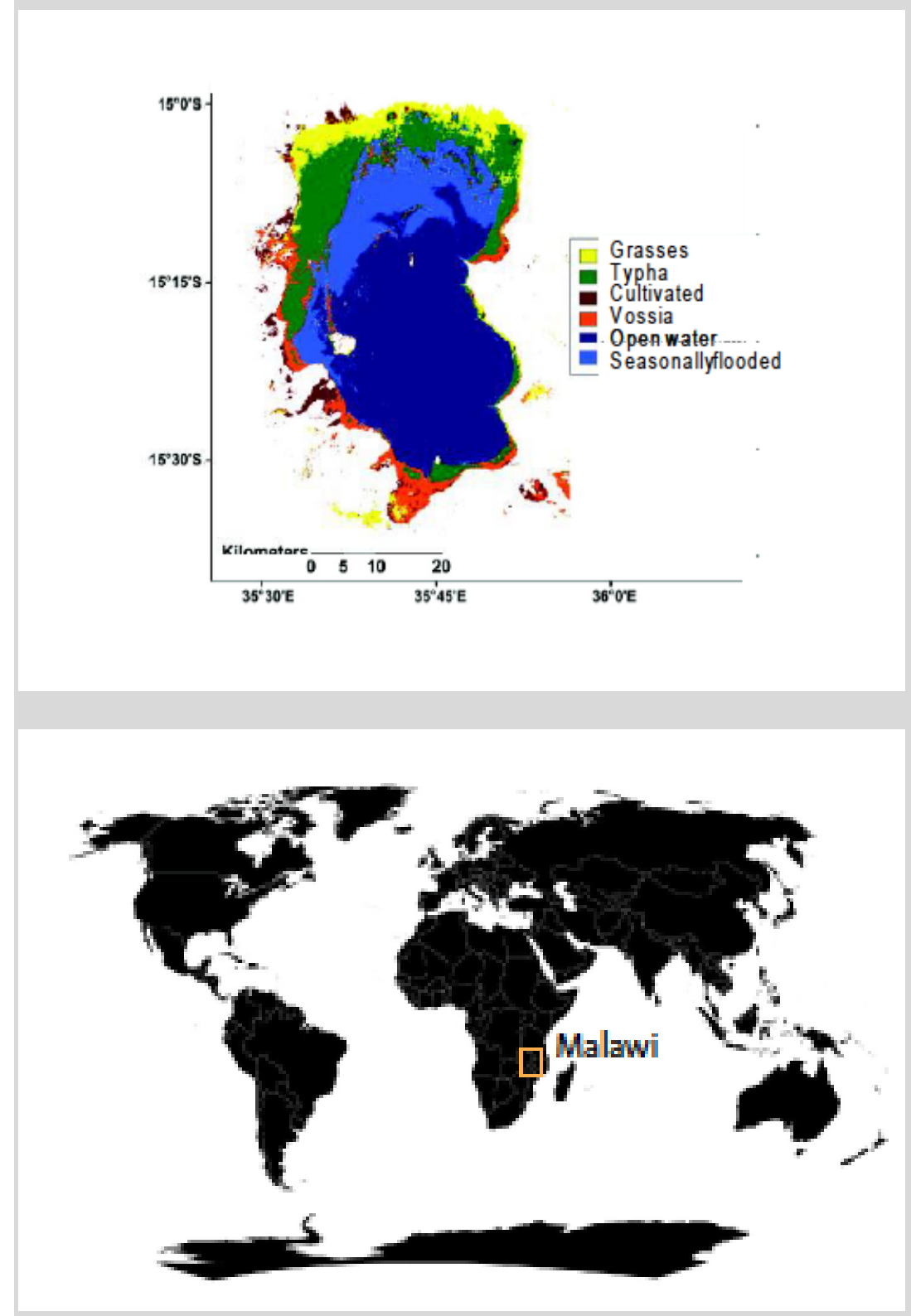

Figure 8.2: Map of Lake Chilwa, Malawi, showing vegetation types (source Lisa-Marie Rebelo, International Water Management Institute).

The lake and surrounding marsh and floodplain were designated as a Ramsar site by Malawi in 1996 on the basis of regularly supporting one percent or more of the individuals in a population of one species or subspecies of a waterbird.

Although Lake Chilwa is one of the most productive lakes in Africa, it is susceptible to major changes such as those seen for fishery catches (Jamu et al, 2006; Rebelo et al, 2011). During productive years, the annual fishery catch was more than 20,000 tonnes, whereas the average over the period 1962-2003 was a much lower 9,000 tonnes. 
The lake is expected to be influenced by changes in the hydrology as a consequence of changes in the inflowing streams, with climate change projections indicating a decrease in the available water. As it is a shallow lake, with high levels of evaporation, it is vulnerable to drying during low rainfall years. Future reduction in lake levels due to increased extraction in the catchment, and to climatic variability, may result in drying of the marsh and grassed floodplain, thereby reducing the productivity of the lake (Jamu et al, 2006). The lake is also under increasing pressure from changes in agriculture in its catchment, and in-lake fisheries, as the human population rises and food demands increase. The "integrated small scale economy of farming, fishing and cattle-rearing" described by Kalk et al. (1979) has changed with less livestock rearing and more cultivation, including irrigation, and fishing (Allison and Mvula, 2002). The Mozambican side of the Lake has a much lower population density and relatively undisturbed forests and a low level of agricultural activity, compared to that in Malawi (Jamu et al, 2006).

Although Malawi has a management plan for the lake, an integrated transboundary plan that encompasses the entire catchment is needed. This is of particular importance due to the seasonal and periodic water-level fluctuations and frequent drying of the lake, which result in shifts in livelihood activities within the wetland and the catchment. The Integrated Lake Basin Management (ILBM) Platform Process (Nakamura and Rast, 2011; Nakamura et al. 2012) provides a positive contribution to such efforts.

A practical lake management approach that considers both the scientific and governance elements is encompassed within the concept of Integrated Lake Basin Management (ILBM), as exemplified in the ILBM Platform Process developed by the International Lake Environment Committee (Figure 8.3). The platform represents a virtual stage for collective stakeholder actions for improving lake basin governance through ILBM, as a strategic means of facilitating its gradual and continuous improvement over time. This approach, which focuses on lakes and other lentic water systems upon which we depend for most of our provisioning ecosystem services, is being increasingly utilized to address lake management issues. Having been applied to lakes in many countries throughout the world, whether as a basic or cyclic process (Nakamura and Rast, 2011) it provides a means to address the abovenoted management elements within an integrated approach focusing on sustainable ecosystem services. It also allows the consideration not only of lakes, but also the other water systems to which they are hydrologically connected in their basins, enhancing its utility for addressing 
conservation issues for other types of water systems as well. In fact, the majority of the accessible freshwater resources on our planet are linked in varying degrees to the lentic - lotic environment, and this linked lentic-lotic environment requires special care in its assessment and management. This aspect is typically overlooked, in spite of its important scientific and management implications, and experience to date indicates that the ILBM Platform Process can play an important complementary role in managing not only lakes and reservoirs, but also the range of other freshwater systems within their basins and beyond.

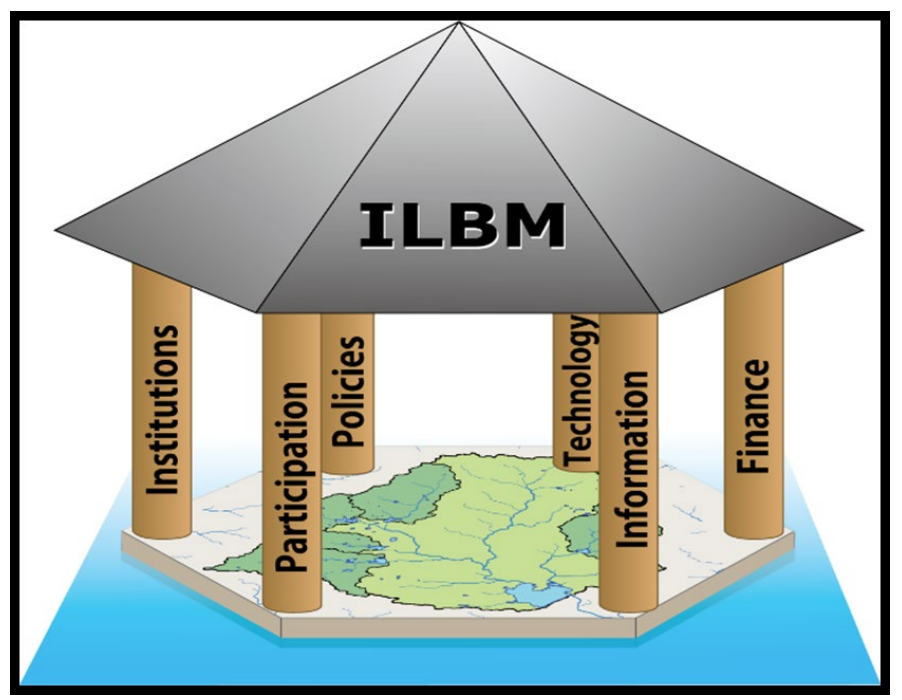

Figure 8.3: Overview of ILBM Governance Framework (Nakamura and Rast, 2014)

\section{Peatland conservation and management}

\section{Peatlands}

Peatlands are widespread and cover around 4 million $\mathrm{km}^{2}$ (Figure 8.4), although in many parts of the world there is a large degree of uncertainty about their extent (Joosten, 2009). There are several definitions of peatlands, but they are generally considered to be areas of land with a naturally accumulated layer of peat, formed from carbon rich dead and decaying plant material under water logged conditions, and generally seen as comprising at least $30 \%$ dry mass of dead organic material and greater than $30 \mathrm{~cm}$ deep. They can develop under a wide range of vegetation types including lowland or upland fens, reed beds, wet woodland, bogs, and under tidal conditions, and in mangroves. At the ecosystem level, the size, shape and biological features of peatlands are determined by climate and geomorphology as well as the quality and quantity of associated water. In Eurasia in particular the term mire is used to refer to wetlands that are actively accumulating peat to differentiate them from the more 
general term peatland that also includes ecosystems where peat is not actively being accumulated (Joosten and Clarke, 2002). For systems where the accumulation of peat has ceased, the term is not applicable.

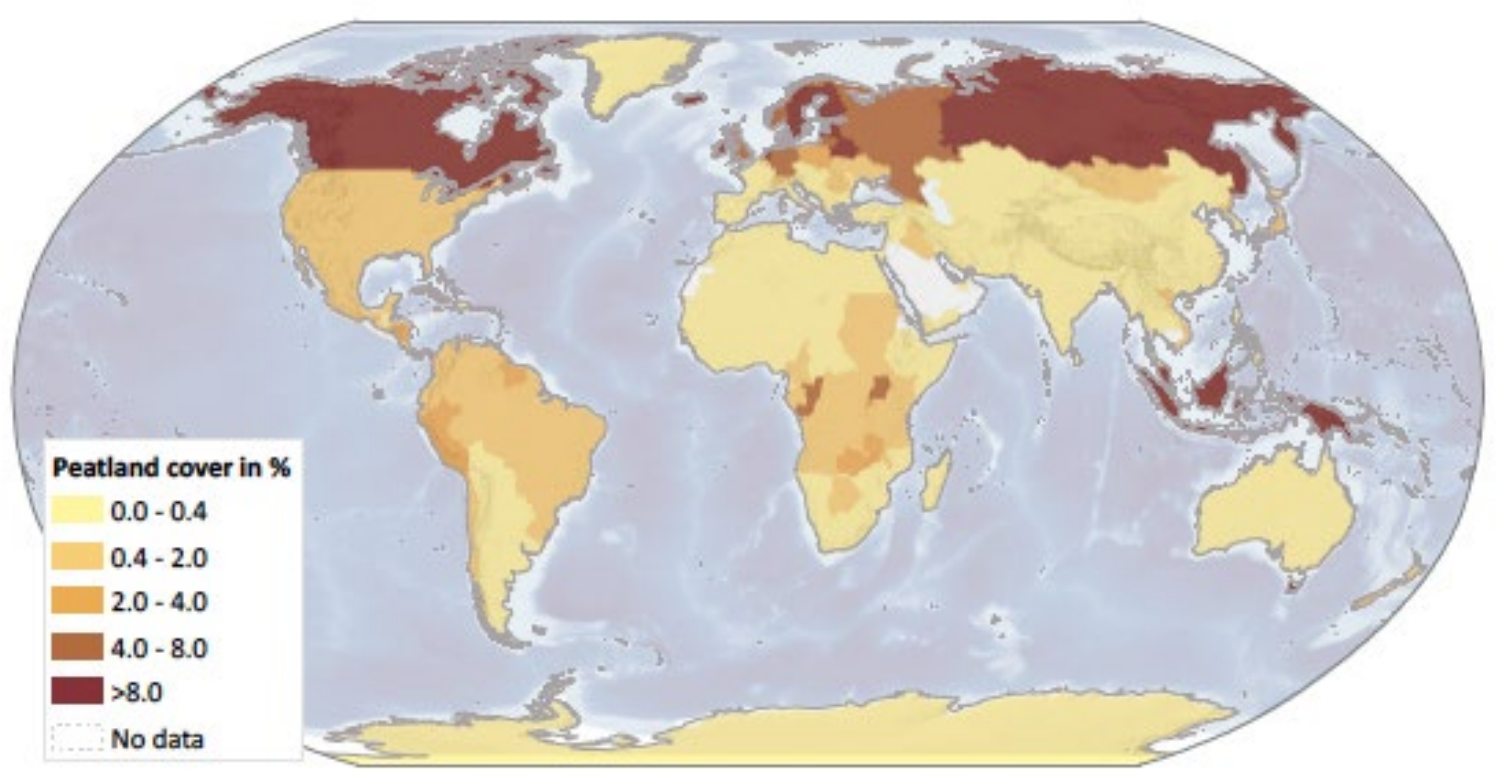

Figure 8.4: Global distribution of peatlands (source IMDG Global Peatland Database, 2014)

Peatlands occur in many countries and could represent more than a third of global wetlands. Joosten $(2009 ; 2010)$ provides an overview of the distribution of freshwater peatlands with peat layers greater than $30 \mathrm{~cm}$ depth, hence excluding shallower peats, drawing on multiple data sources. The largest areas are found in the northern hemisphere, especially in the boreal zone with 1,375, $690 \mathrm{~km}^{2}$ in Russia and 1,133,926 $\mathrm{km}^{2}$ in Canada. Estimates of peatlands in tropical regions range from 275,424 to $570,609 \mathrm{~km}^{2}$, although most of the data are from pre1990 sources and there has been extensive destruction in recent years (Hooijer et al. 2010). These data do not extend to analyses of the distribution of peatlands in freshwater protected areas. The Ramsar site database (www.ramsar.org; accessed 13 Nov 2016) lists 584 wetlands of international importance that contain peatland, $26 \%$ of the total number of listed sites, covering $53.79 \mathrm{M}$ ha.

\section{Importance of peatlands}

The importance of peatlands is well known, although this has not prevented their degradation. They contain $10 \%$ of the global freshwater volume and are significant in maintaining freshwater quality and hydrological integrity of many river valleys. They play an important 
role in maintaining permafrost and preventing desertification. In recent years their importance as global carbon stores and sinks has come to the fore as the global community addresses measures to mitigate climate change (Lindsay 2010; Hooijer et al. 2010; Joosten 2009, Jossten et al. 2012). Peatlands support important biological diversity and refugia for some of the rarest and most unusual species of wetland-dependent flora and fauna (Joosten and Clarke 2002). Under waterlogged conditions they preserve a unique palaeo-ecological record, including valuable archaeological remains and records of environmental contamination. They support human needs for food, fresh water, shelter, heating, warmth, and employment (Joosten and Clarke, 2002).

\section{Management issues}

Human pressures on peatlands are both direct, through drainage, land conversion (e.g. for oil palms and oil sands), excavation and inundation, and indirect, as a result of air pollution, water contamination, water removal and infrastructure development. When they are destroyed peats release large amounts of carbon and are not easily restored. In response to the degradation of peatlands the Ramsar Convention has adopted detailed Guidelines for Global Action on Peatlands (Ramsar Convention, 2002) including:

- Establishing a global database of peatlands;

- Detecting changes and trends in the quantity and quality of peatlands;

- Developing and promoting education, training, and public awareness programmes;

- Reviewing national networks of peatland PAs;

- Developing and implementing peatland management guidelines and actions plans;

- Establishing regional centres of expertise and research networks; and

- Stimulating international cooperation on research and technology transfer.

Recent initiatives have stimulated actions to limit the loss of carbon from peatlands and to encourage their retention and restoration as part of climate change mitigation measures (Joosten et al., 2012; Biancalani and Avagyan, 2014). This is particularly important given the past loss of peatlands globally and the more recent degradation of tropical peatlands (Hooijer et al. 2010; Joosten et a1., 2012). Approaches for restoring northern peatlands are well established (Quinty and Rochefort, 2003) and are being developed for tropical systems (Page et al., 2009). 


\section{Groundwater-dependent ecosystems}

\section{What are GDEs?}

The notion of groundwater-dependent ecosystems (GDEs) implies groundwater is an important contributor to the maintenance of the hydrological regime supporting the ecosystem. Furthermore, a change in the quantity or quality of groundwater, often associated with human activity, will impact on the state and condition of the ecosystem (Eamus and Froend, 2006).

Richardson et al (2011a) recognised three types of groundwater dependent ecosystems:

- aquifer and cave ecosystems which provide unique habitats for living organisms (e.g. stygofauna and troglofauna, the animals that live underground), including karst aquifer systems, fractured rock and saturated sediments;

- ecosystems fully or partly dependent on the surface expression of groundwater including wetlands, lakes, seeps, springs, river baseflow, coastal areas, estuaries and marine ecosystems;

- ecosystems dependent on subsurface presence of groundwater (via the capillary fringe) including terrestrial vegetation that depends on groundwater fully or on an irregular basis to meet water requirements

The degree of dependence on groundwater relative to other sources of water is important in differentiating these ecosystems and their response to changes in groundwater availability (Eamus et al, 2006). Of particular significance are the spatial and temporal variability in water tables and the nature of groundwater discharge into flowing or still surface water bodies. According to these interactions, different physicochemical properties and species assemblages will develop and become characteristic of the predominant hydrological regime (Horwitz et al, 2008).

\section{Management issues}

Interest in GDEs has largely developed from a need to understand the consequences of direct use or pollution of aquifers that maintain ecosystems. Management issues arise when the conditions under which groundwater contributes to the maintenance of GDEs are disrupted by human activity. Both the quantity and quality of groundwater is important as well as the 
spatial and temporary variability. These relationships can be disrupted by changes to the groundwater through abstraction, pollution and reduction in rainfall recharge. Effective management of GDEs therefore requires integration of associated surface and groundwater resources and necessitates an understanding of the origins, pathways and storages of water. For example, some GDEs are entirely maintained by continuous groundwater discharge whilst others are maintained by minor but critical groundwater inflows restricted to particular seasons or inter-annual episodes.

In general, processes that threaten GDEs are no different to those that threaten other ecosystems. Changes in groundwater can arise from reduced rainfall recharge, land clearing, forestry and agriculture, urbanisation and direct groundwater abstraction for water supply. The ecological changes brought about by these activities will vary between types of GDEs, depending on their hydrological requirements (Richardson et al, 2011a). Any significant change to the quantity and quality of groundwater can be expected to have an impact on the associated biota and ecological processes. Hatton and Evans (1998) identified types of GDEs that differed in their 'degree of dependence' on groundwater, and the impact of altered groundwater regimes was considered proportional to inferred ecosystem dependence. Identifying the importance of groundwater in ecosystems prior to development of groundwater resources (or other activities in a catchment) will inform resource planning and potential trade-offs against increasing demand for drinking water. The array of current approaches to identifying groundwater requirements of GDEs are summarised by (Richardson et al, 2011b) and range from measurement of groundwater transpiration by individual trees to hydrological water balances and remote sensing at the landscape scale. In most cases an integration of different approaches and associated disciplines and knowledge is required to adequately understand the potential responses of GDEs to altered water regimes. Management of GDEs can also be informed by improved understanding of the potential for ecosystems to adapt to change in groundwater availability. For example, some GDEs of the Swan Coastal Plain in Western Australia may have shifted to an alternative state (defined by biota and ecological processes that correspond to a particular groundwater regime) in accordance with changes in the extant hydrological support conditions (Froend and Sommer, 2010; Sommer and Froend, 2014). However, the potential of GDEs to adapt can be limited under catastrophic (and largely irreversible) changes in the availability of groundwater, such as the exacerbation of drought-induced drawdown by groundwater abstraction, which has resulted in widespread mortality of groundwater dependent (phreatophytic) vegetation 
(Sommer and Froend, 2011). In response, management agencies have assessed the threats to phreatophytic vegetation (Barron et al., 2014) and restricted groundwater pumping near vulnerable wetland ecosystems to enhance the potential for GDEs to adapt (McFarlane et al., 2012). In order to avoid such scenarios, adaptive management actions aimed at applying learned outcomes, integrating catchment management and balancing water demands with conservation, are required.

\section{Estuary management and conservation}

\section{Estuaries}

Estuaries are among the most complex of all the types of freshwater or freshwater-dependent ecosystems discussed in this chapter. Their position at the interface of the terrestrial and marine environment makes them vulnerable to the impacts of just about all human activities, whether land-based, freshwater or marine, including the impacts of climate change. To add to these pressures, estuaries tend to be a magnet for human activity, irrespective of their protection status. Thus managing estuaries as PAs can be particularly challenging, and its effectiveness often depends on managing external influences even more than on managing in situ activities. Thus the successful management of estuarine PAs hinges on co-operative governance between a range of government agencies.

\section{Managing hydrodynamics and water quality}

Estuarine functioning is primarily driven by the quantity and quality of freshwater inputs and their temporal distribution, in conjunction with inputs from the marine environment, with the former having a major influence on the latter (Allanson and Baird, 1999; Borja et al, 2011; Whitfield et al, 2012). Mediated by freshwater inflows and tides, fresh and salt waters mix in a nutrient rich environment that supports a diversity of aquatic species. Run-of-river freshwater abstraction, large impoundments and small farm dams are mainly responsible for the decrease in the overall quantity of freshwater entering estuaries. On the other hand, interbasin transfer schemes, waste water treatment works and increased runoff from 'hardened' catchments (e.g. road networks) are responsible for increased freshwater inflow that historically received a lower inflow (Nirupama and Simonovic, 2007).

Ideally, the freshwater flow into an estuary should be maintained in all its variability, as the components of a system's natural flow regime support its overall habitat structure and dynamics (van Niekerk and Turpie, 2012). Base flows are generally responsible for maintaining the salinity regime, and in the case of temporarily open systems, their 
connectivity to the sea (mouth state). In contrast, floods shape the geomorphological aspects such as size and shape of an estuary and its characteristic sediment structure. These processes also help to maintain the linkages between estuaries and their surrounding terrestrial, freshwater and marine systems. The life history strategies of many species involve movement between these systems, for which the maintenance of open mouth conditions at the right time of year is essential. This includes many marine species of conservation and commercial value whose populations and viability depend on well-functioning networks of estuaries. Thus, although they are discrete ecosystems, estuaries should not be managed as isolated systems (van Niekerk and Turpie, 2012).

In addition to the quantity of water entering estuaries, catchment activities and infrastructure also affect the quality of this water, in terms of the loads of sediments, nutrients and other pollutants entering the system (Turner et al, 2004). This can result in smothering of habitats, increased turbidity and eutrophication, all of which can result in significant changes in biotic communities, and local extinctions. While some of the pollution entering estuaries arises from estuary users and adjacent settlements, these are largely problems that arise from the entire catchment area, and cannot be effectively dealt with by protected area managers operating within the system.

The protection of an estuary therefore entails ensuring that the quantity and quality of freshwater inflows are maintained as close to natural as possible, in order to maintain ecological functioning and biodiversity in a relatively natural state. In reality, however, estuary managers have to deal with many changes that are difficult to reverse to the extent desired, if at all. Where this is the case, protection of estuaries can involve imposing artificial means such as flood-flow releases from dams, and breaching the estuary artificially. These interventions are far more complex than trying to maintain natural processes, and require considerable investment in research and monitoring in order to devise strategies that can achieve conservation goals. The Chilika Lagoon (see Box 8.2) is such an example.

\section{Managing in-situ pressures on habitats and biota}

The main pressures that have to be managed within estuary systems are developments that encroach on estuary habitats, harvesting of resources such as fish and mangroves, aquaculture, human disturbance and the eradication or control of invasive alien species (Perissinotto et al, 2013). 
While population and development tends to be concentrated along the coast generally, estuaries are particularly attractive, due to their productivity and their suitability for harbours, aquaculture and recreation. Estuarine PAs can limit this development, especially when they are part of terrestrial PAs, but often have dense development on their boundaries. With this comes a high level of industrial or recreational use. It is rare that estuaries are included entirely within large PAs that buffer them from intense use, and in many instances, PAs are either limited to part of an estuary, or incorporate multiple uses through zonation.

Managing the use of an estuary involves making trade-offs between the different types of value that it can generate (Turpie et al, 2007). For example, allowing subsistence fishing or angling will impact on the provision of ecosystem services such as their functioning as nursery areas to support marine fisheries, and allowing excessive development and access will impact on the biodiversity of the system and its value as an ecotourism destination.

\section{Key interventions}

In order for protection of estuaries to be successful, all of the following interventions at the local to national scale will be necessary:

- Integrated conservation planning that takes landscape processes and socio-economic trade-offs into account (see Turpie and Clark, 2007);

- Catchment management and the setting of environmental flow requirements to assure provision of adequate quantity and quality of inflows to maintain the protected estuaries in a desired state of health (Adams, 2013);

- The development of management plans to control competing uses within estuaries;

- Effective restriction of consumptive use to prioritise conservation of biodiversity and the supply of regulating services such as nursery areas for crustaceans and fish, carbon sequestration and coastal protection;

- Delineation of development setback lines to protect landscape value as well as to accommodate mouth migration, and water levels associated with changes in mouth state and sea level rise.

- Variability in abiotic drivers is a critical natural stress in estuaries, this manifest itself as variability in flow, water levels, salinity regimes, oxygen, turbidity, morphology and ultimately biota. A natural outcome of water resource development is the 
regulation of flow and the inability to provide the natural resetting stresses required to ensure long-term productivity. Loss of regular stresses ultimately reduces a estuaries natural resilience to events such as floods and droughts in the future.

- Ensuring connectivity to both catchment and sea is key to estuary health and productivity. This speaks to the need for "free flowing rivers" and the mitigation of impoundment barriers (e.g. fish ladders) as well as less clearly defined "obstructions", e.g. poor water quality (low oxygen) can act as a migration barriers, while predatory alien invertebrate / fish species can similarly disrupt/prevent the natural flow of species and genes.

Geoscience Australia (2013) and EPA (2012) provide further information and guidelines for good estuarine management.

\section{Box 8.2: Restoration of Lake Chilika, India}

Chilika is a brackish coastal lagoon situated in Orissa State, India. It covers an area of 906 $\mathrm{km}^{2}$ to $1,165 \mathrm{~km}^{2}$ in the dry and wet seasons, respectively, being flanked by an ephemeral floodplain of $400 \mathrm{~km}^{2}$ (see Figure 8.5). It comprises shallow to very shallow marine, brackish and freshwater ecosystems with estuarine characters, and is a hotspot of biodiversity with more than one million overwintering migratory birds (Kumar and Pattnaik, 2012). It is also one of only two lagoons that support the Irrawaddy Dolphin (Orcaella brevirostris). The diverse and dynamic assemblage of fish, invertebrates and crustaceans supports a rich fishery that generates more than USD $\$ 17.3$ million of annual revenue. Chilika was designated as a Wetland of International Importance (Ramsar Site) in 1981.

\section{Degradation}

Sustained provision of the wide range of ecosystem services of Chilika and maintenance of the livelihoods of dependent communities, including some 0.2 million fishers and 0.4 million farmers, is associated with the coastal and freshwater hydrology of the lagoon. From 19502000 , increased sediment from a degrading catchment reduced the connectivity of the lagoon to the sea, causing a rapid decline in fisheries (Mohapatra et al, 2007). The introduction of shrimp culture, as well as the decline in fisheries, led to the breakdown of traditional resource management systems, with a loss of traditional occupations, and resentment between 
traditional fishers and immigrants (Dujovny, 2009). Due to changes in ecological characteristics Chilika was included in the Montreux Record by Ramsar in 1993.

\section{Restoration}

The Government of Odisha created the Chilika Development Authority (CDA) in 1991 as a node for the ecological restoration of the lake, chaired by the Chief Minister and comprising senior representatives of all concerned departments, as well as representatives of the fishing communities. It has established programmes for catchment restoration, hydro-biological monitoring, sustainable development of fisheries, wildlife conservation, community participation and development and capacity building. In 2000, it was agreed to create a channel to reconnect the lagoon to the sea - a major intervention based on modelling and stakeholder consultations. An intensive awareness campaign about the values and functions of the lake was undertaken, and a hydro-ecological monitoring programme put in place. These programmes are coordinated through the Wetland Research and Training Center constructed on the shoreline of Chilika in 2002.

Restoration of the hydrological regime and re-establishment of the salinity regime (Ghosh et al, 2006) led to the recovery of the fisheries and biodiversity. The average fish landing increased from 1,747 MT in 2000 to 14,228 MT in 2012. The Irrawaddy Dolphin population increased from 89 to 142 individuals between 2003 and 2012. The sea grass meadows expanded from $20 \mathrm{~km}^{2}$ in 2000 to $80 \mathrm{~km}^{2}$. There has also been a decline in the area covered by invasive weeds. These ecological improvements, in particular the increase in dolphins, led to a resurgence of community based ecotourism. The success of these interventions was recognized with the Ramsar Wetland Conservation Award and Evian Special Prize for "wetland conservation and management initiatives." Chilika Lake was also removed from the Montreux Record by Ramsar Convention in 2002 due to improvements in its ecosystem.

An integrated management planning process involving key stakeholders was initiated in 2008 to guide the ongoing conservation and wise use of Chilika. A management planning framework was developed (Kumar and Pattnaik, 2012), with a plan being released by the Chief Minster in October 2012. The CDA also initiated a programme for the revitalization of a community-based fisheries institution with the State Government establishing the Chilika Fishermen Central Cooperative Society (CFCCS) Ltd in July 2010. 


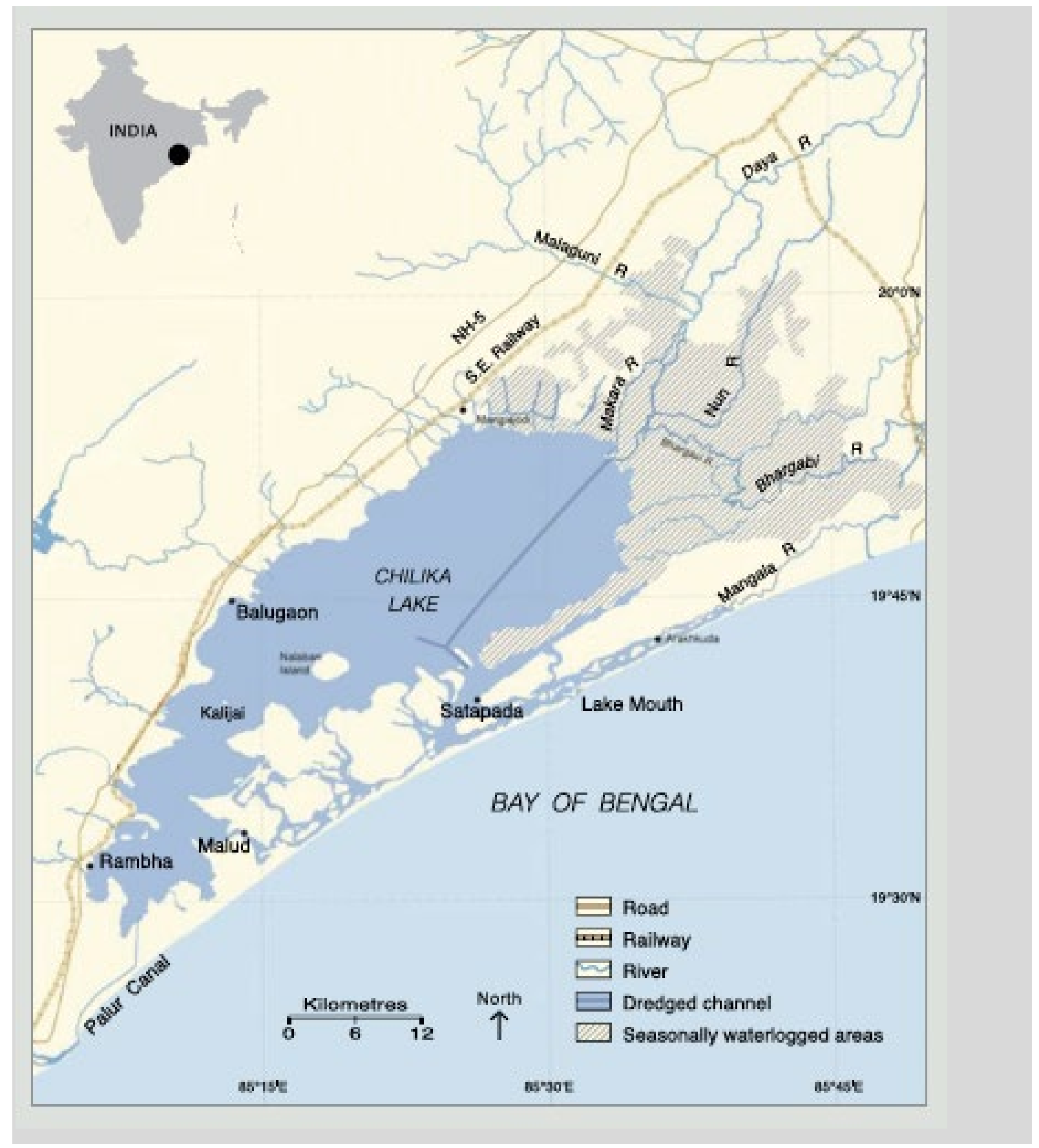

Figure 8.5: Map of Chilika Lagoon, India (source Chilika Development Authority and Wetlands International - South Asia) 


\section{Literature Cited}

Abell, R., Allan, J.D. and Lehner, B. (2007) 'Unlocking the potential of protected areas for freshwaters', Biological Conservation, vol 134, pp48-63

Adams, J.B. (2013) 'A review of methods and frameworks used to determine the environmental water requirements of estuaries', Hydrological Sciences Journal, vol 59, pp451-465

Allan, D., Esselman, P., Abell, R., McIntyre, P., Tubbs, N., Biggs, H., Castello, L., Jenkins, A. and Kingsford, R. (2010) 'Protected areas for freshwater ecosystems: Essential but underrepresented'. In Mittermeier, R.A., Farrell, T., Harrison, I.J., Upgren, A.J., Brooks, T. (eds) Fresh water: the essence of life, CEMEX and ILCP, Arlington.

Allanson, B. and Baird, D. (eds) (1999) 'Estuaries of South Africa', Cambridge University Press, New York

Allison, E.H. and Mvula, P.M. (2002) Fishing livelihoods and fisheries management in Malawi. LADDER Working Paper No 22, Department for International Development, London

Arthington, A.H. (2012) Environmental flows. Saving rivers in the Third Millennium,University of California Press, Berkeley

Arthington, A.H., Bunn, S.E., Poff, N.L. and Naiman, R.J. (2006) 'The challenge of providing environmental flow rules to sustain river ecosystems', Ecological Applications, vol 16, pp1311-1318

Arthington, A.H., Finlayson, C.M. and Pittock, J. (2107) 'Freshwater ecological principles'. In Finlayson, C.M., Arthington. A.H. and Pittock, J. (eds), Freshwater Ecosystems in Protected Areas: Conservation and Management. Taylor and Francis, Oxford, UK. Arthington, A.H., Rall, J.L., Kennard, M.J. and Pusey, B.J. (2003) 'Environmental flow requirements of fish in Lesotho Rivers using the DRIFT methodology', River Research and Applications, vol 19, pp641-666

Barron, O., Froend, R.H., Hodgson, G., Ali, R., Dawes, W., Davies, P. and McFarlane, D. (2013) 'Projected risks to groundwater-dependent terrestrial vegetation caused by changing climate and groundwater abstraction in the Central Perth Basin, Western Australia', Hydrological Processes, DOI: 10.1002/hyp.10014 
Brauman, K.A., Daily, G.C., Duarte, T.K.E. and Mooney, H.A. (2007) 'The nature and value of ecosystem services: an overview highlighting hydrologic services', Annual Review of Environment and Resources, vol 32, pp67-98

Boerema, A., Rebelo, A. J., Bodi, M. B., Esler, K. J. and Meire, P. (2016) 'Are ecosystem services adequately quantified?', Journal of Applied Ecology, doi:10.1111/1365-2664.12696 Biancalani, R. and Avagyan A. editors (2014) Towards climate-responsible peatlands management. Rome: Food and Agriculture Organization of the United Nations (FAO), p. 117.

Bovee, K.D. (1982) A guide to stream habitat analysis using the IFIM, US Fish and Wildlife Service Report FWS/OBS-82/26, Fort Collins

Brisbane Declaration 2007. Environmental Flows are Essential for Freshwater Ecosystem Health and Human Well-Being. Declaration of the 10th International River Symposium and International Environmental Flows Conference, 3-6 September 2007: Brisbane, Australia. (http://www.eflownet.org)

Bunn, S.E. and Arthington, A.H. (2002) 'Basic principles and ecological consequences of altered flow regimes for aquatic biodiversity', Environmental Management, vol 30, pp492507

Butchart, S.H., Clarke, M., Smith, R.J., Sykes, R.E., Scharlemann, J.P., Harfoot, M., Buchanan, G.M., Angulo, A., Balmford, A., Bertzky, B. and Brooks, T.M. (2015) 'Shortfalls and solutions for meeting national and global conservation area targets', Conservation Letters, vol 8(5), pp329-337

Chan, T.U., Hart, B.T., Kennard, M.J., Pusey, B.J., Shenton, W., Douglas, M.M., Valentine, E. and Patel, S. (2012) 'Bayesian network models for environmental flow decision making in the Daly River, Northern Territory, Australia', River Research and Applications, vol 28, pp283-301

Commonwealth of Australia (2012) Basin plan, Commonwealth of Australia, Canberra Cumming, G.S. (2016) 'The relevance and resilience of protected areas in the Anthropocene', Anthropocene, vol 13, pp46-56

Davies, P.M., Naiman, R.J., Warfe, D.M., Pettit, N.E., Arthington, A.H. and Bunn, S.E. (2014) 'Flow-ecology relationships: closing the loop on effective environmental flows', Marine and Freshwater Research, vol 65, pp133-141 
Dodson, S. (2005) Introduction to Limnology, McGraw-Hill, New York

Dudgeon, D., Arthington, A.H., Gessner, M.O., Kawabata, Z.I., Knowler, D.J., Lévêque, C., Naiman, R.J., Prieur-Richard, A.H., Soto, D. and Stiassny, M.L. (2006) 'Freshwater biodiversity: importance, threats, status and conservation challenges', Biological Reviews, vol 81, pp163-182

Dujovny, E. (2009) 'The deepest cut: Political ecology in the dredging of a new sea mouth in Chilika Lake, Orissa, India', Conservation \& Society, vol 7, pp 192-204

Dyson, M., Bergkamp, G. and Scanlon, J. (eds) (2003) Flow: The Essentials of Environmental Flows, IUCN, Gland

Eamus, D. and Froend, R. (2006) 'Groundwater-dependent ecosystems: the where, what and why of GDEs', Australian Journal of Botany, vol 54, pp91-96

Eamus, D., Froend, R., Loomes, R., Hose, G. and Murray, B. (2006) 'A functional methodology for determining the groundwater regime needed to maintain the health of groundwater-dependent vegetation', Australian Journal of Botany, vol 54, pp97-114

Finlayson, C.M., Davidson, N.C., Gell, P.A., Kumar, R. and McInnes, R.J. (2107) 'Managing freshwater protected areas in the global landscape'. In Finlayson, C.M., Arthington. A.H. and Pittock, J. (eds), Freshwater Ecosystems in Protected Areas: Conservation and Management. Taylor and Francis, Oxford, UK.

Froend, R. and Sommer, B. (2010) 'Phreatophytic vegetation response to climatic and abstraction-induced groundwater drawdown: Examples of long-term spatial and temporal variability in community response', Ecological Engineering, vol 36, pp1191-1200

García-Llorente, M., Harrison, P.A., Berry, P., Palomo, I., Gómez-Baggethun, E., IniestaArandia, I., Montes, C., del Amo, D.G. and Martín-López, B. (2016) 'What can conservation strategies learn from the ecosystem services approach? Insights from ecosystem assessments in two Spanish protected areas' Biodiversity and Conservation, doi:10.1007/s10531-016$1152-4$

GWP (2000) Integrated Water Resources Management, Global Water Partnership, Stockholm Harrison, I.J., Green, P.A., Farrell, T.A., Juffe-Bignoli, D., Sáenz, L. and Vörösmarty, C.J. (2016) 'Protected areas and freshwater provisioning: a global assessment of freshwater provision, threats and management strategies to support human water security', Aquatic Conservation: Marine and Freshwater Ecosystems, vol 26(S1), pp103-120 
Herbert ME, Mcintyre PB, Doran PJ, Allan JD, and Abell R. (2010) 'Terrestrial reserve networks do not adequately represent aquatic ecosystems', Conservation Biology, vol 24, pp1002-1011

Hooijer, A., Page, S., Canadell, J.G., Silvius, M., Kwadijk, J., Wösten, H. and Jauhiainen, J. (2010) 'Current and future $\mathrm{CO}_{2}$ emissions from drained peatlands in Southeast Asia', Biogeosciences, vol 7, pp1505-1514

Horwitz, P., Bradshaw, D., Hopper, S., Davies, P., Froend, R. and Bradshaw, F. (2008) 'Hydrological change escalates risk of ecosystem stress in Australia's threatened biodiversity hotspot', Journal of the Royal Society of Western Australia, vol 91, pp1-11

Illueca, J. and Rast, W. (1996) Precious, finite and irreplaceable. Our Planet, vol, 8, http://www.ourplanet.com/imgversn/83/rast.html

ILEC (International Lake Environment Committee) (2005). Managing Lakes and Their Basins forSustainable Use. A Report for Lake Basin and Stakeholders. International Lake Environment Committee, Kusatsu, Japan. 146. p. (http://www.ilec.or.jp/en/pubs/p2/lbmi) IPCC (2007) Impacts, adaptation and vulnerability. Intergovernmental Panel on Climate Change Climate Change 2007: Working Group II. Contribution to the Intergovernmental Panel on Climate Change Fourth Assessment Report, International Panel on Climate Change, Geneva

Jackson, R.B., Carpenter, S.R., Dahm, C.N., McKnight, D.M., Naiman, R.J., Postel. S.L., Running, S.W. (2001) 'Water in a changing world', Ecological Applications, vol 11, pp10271045.

Jamu, D., Delaney, L.M. and Campbell, C.E. (2006) Transboundary management plan for the Lake Chilwa catchment area, Association of Universities and Colleges of Canada, Ottawa Joosten, H. (2009) The global peatland CO2 picture: Peatland status and drainage related emissions in all countries of the world, Greifswald University \& Wetlands International, Waganingen

Joosten, H. and Clarke, D. (2002) Wise use of mires and peatlands - background and principles including a framework for decision-making, International Mire Conservation Group and International Peat Society, Saarijärvi 
Joosten, H., Tapio-Biström, M.L. and Tol, S. (eds) (2012) Peatlands - guidance for climate change mitigation through conservation, rehabilitation and sustainable use, FAO and Wetlands International, Rome and Ede

Jorgensen, S., Loffler, H., Rast, W. and Straskraba, M. (2005) Lake and Reservoir Management, Elsevier, Amsterdam

Kalff, J. (2002) Limnology,Prentice Hall, Upper Saddle River

Kalk, M., McLachlan, A. and Howard Williams, C. (1979) Lake Chilwa: studies of change in a tropical ecosystem,Dr. W. Junk, The Hague

King, J., Brown, C. and Sabet, H. (2003) 'A scenario-based holistic approach to environmental flow assessments for rivers', River Research and Applications, vol 19, pp619639

Kingsford, R.T., Biggs, H.C. and Pollard, S.R. (2011a) 'Strategic adaptive management in freshwater protected areas and their rivers', Biological Conservation, vol 144, pp1194-1203

Kumar, R. and Pattnaik, A.K. (2012) Chilika-An Integrated Management Planning Framework for Conservation and Wise Use, Wetlands International - South Asia and Chilika Development Authority, New Delhi and Bhubaneswar

Lindsay, R. (2010). Peatlands and carbon: a critical synthesis to inform policy development in oceanic peat bog conservation and restoration in the context of climate change. RSPB, Scotland.

Martín-López, B., Gómez-Baggethun, E., García-Llorente, M., Montes, C. (2014) 'Trade-offs across value-domains in ecosystem services assessment', Ecological Indicators, vol 37, pp220-228

McFarlane, D., Strawbridge, M., Stone, R. and Paton, A. (2012) 'Managing groundwater levels in the face of uncertainty and change: a case study from Gnangara', Water Science and Technology: Water Supply, vol 12, pp321-328

McLoughlin, C. A., and Thoms, M.C. (2015) 'Integrative learning for practicing adaptive resource management, Ecology and Society, vol 20(1), http://dx.doi.org/10.5751/ES-07303200134

MEA (Millennium Ecosystem Assessment) (2005) Ecosystems and human well-being: wetlands and water synthesis, World Resources Institute, Washington DC 
Mohapatra, A., Mohanty, R.K., Mohanty, S.K., Bhatta, K.S. and Das, N.R. (2007) 'Fisheries enhancement and biodiversity assessment of fish, prawn and mud crab in Chilika lagoon through hydrological intervention', Wetlands Ecology and Management, vol 15, pp229-251

Neave, I., McLeod, A., Raisin, G., and Swirepik, J. (2015) 'Managing water in the MurrayDarling Basin under a variable and changing climate', AWA Water Journal, vol 42, pp102107

Nel, J.L., Reyers, B., Roux, D.J. and Cowlingc, R.M. (2009) 'Expanding protected areas beyond their terrestrial comfort zone: Identifying spatial options for river conservation', Biological Conservation, vol 142, pp1605-1616

Nakamura, M, and Rast, W. (2011). Development of ILBM Platform Process. Evolving Guidelines through Participatory Improvement. Research Center for Sustainability and Environment, Shiga University, and International Lake Environment Committee, Kusatsu, Japan. 76 p. (http://www.ilec.or.jp/en/pubs/p2/ilbm-platform-process).

Nakamura, M., Rast, W., Kagatsume, T. and Tomohiro, S. (2012). Primer: Development of ILBM Platform Process. Evolving Guidelines through Participatory Improvement. Research Center for Sustainability and Environment, Shiga University, and International Lake Environment Committee, Kusatsu, Japan. 26 p. (http://www.ilec.or.jp/en/pubs/p2/primerilbm-platform-process).

Nel, J.L., Roux, D.J., Maree, G., Kleynhans, C.J., Moolman, J., Reyers, B., Rouget, M. and Cowling, R.M. (2007) 'Rivers in peril inside and outside protected areas: a systematic approach to conservation assessment of river ecosystems', Diversity and Distributions, vol 13 , pp341-352

Osborn, D., Cutter, A. and Ullah, F. (2015) 'Universal sustainable development goals. Understanding the transformational challenge for developed countries', Report the Stakeholder Forum, IUCN Global Gender Office, Washington D.C.

O'Sullivan, P.E. and Reynolds, C.S. (2004) The Lakes Handbook: Limnology and Limnetic Ecology,Blackwell Publishing, Oxford

Page S., Hoscilo A., Wösten H., Jauhiainen J., Silvius M., Rieley J., Ritzema H., Tansey K., Graham L., Vasander H. and Limin S. (2009) 'Restoration ecology of lowland tropical peatlands in Southeast Asia: current knowledge and future research directions' Ecosystems, vol 12, pp888-905. 
Pahl-Wostl, C., Sendzimir, J., Jeffrey, P., Aerts, J., Berkamp, G., Cross, K. (2007) 'Managing change toward adaptive water management through social learning', Ecology and Society, vol 12

Palmer, M.A., Reidy Liermann, C.A., Nilsson, C., Flörke, M., Alcamo, J., Lake, P.S. and Bond, N. (2008) 'Climate change and the world's river basins: anticipating management options', Frontiers in Ecology and the Environment, vol 6, pp81-89

Palomo, I., Montes, C., Martín-López, B., González, J.A., García-Llorente, M., Alcorlo, P. and Mora, M.R.G. (2014) 'Incorporating the social-ecological approach in Protected Areas in the Anthropocene', BioScience, vol 64, pp181-191

Pittock, J. and Finlayson, C.M. (2013) 'Climate change adaptation in the Murray-Darling Basin: reducing resilience of wetlands with engineering', Australian Journal of Water Resources, vol 17, pp161-168

Pittock, J., Baumgartner, L., Finlayson, C.M., Thiem, J.D., Forbes, J.P., Silva, L.G.M. and Arthington, A.H. (2017) 'Managing threats to freshwater systems within protected areas', In Finlayson, C.M., Arthington. A.H. and Pittock, J. (eds), Freshwater Ecosystems in Protected Areas: Conservation and Management. Taylor and Francis, Oxford, UK.

Poff, N.L., Allan, J.D., Bain, M.B., Karr, J.R., Prestegaard, K.L., Richter, B.D., Sparks, R.E. and Stromberg, J.C. (1997) 'The natural flow regime: a paradigm for river conservation and restoration', Bioscience, vol 47, pp769-784

Poff, N.L., Allan, J.D., Palmer, M.A., Hart, D.D., Richter, B.D., Arthington, A.H., Rogers, K.H., Meyer, J.L. and Stanford, J.A. (2003) 'River flows and water wars: emerging science for environmental decision making', Frontiers in Ecology and the Environment, vol 1, pp298306

Poff, N.L., Richter, B.D., Arthington, A.H., Bunn, S.E., Naiman, R.J., Kendy, E., Acreman, M., Apse, C., Bledsoe, B.P., Freeman, M.C., Henriksen, J., Jacobson, R.B., Kennen, J.G., Merritt, D.M., O’Keeffe, J.H., Olden, J.D., Rogers, K., Tharme, R.E. and Warner, A. (2010) 'The ecological limits of hydrologic alteration (ELOHA): a new framework for developing regional environmental flow standards', Freshwater Biology, vol 55, pp147-170 Pollard, S. and Du Toit, D. (2008) 'Integrated water resource management in complex systems: How the catchment management strategies seek to achieve sustainability and equity in water resources in South Africa', Water SA, vol 34, pp671-679 
Quinty, F. and Rochefort L. (2003) Peatland restoration guide. 2nd ed. Québec: Canadian Sphagnum Peat Moss Association. Joint publication with New Brunswick Department of Natural Resources and Energy.

Ramsar Convention (2002) Guidelines for Global Action on Peatlands. Resolution VIII.17, 8th Meeting of the Conference of the Contracting Parties to the Convention on Wetlands (Ramsar, Iran, 1971) Valencia, Spain, 18-26 Nov 2002. Available from: http://www.ramsar. org/sites/default/files/documents/pdf/res/key_res_viii_17_e.pdf _. Accessed 23 Jan 2016.

Rast, W. and Straskraba, M. (2000) Lakes and reservoirs: Similarities, differences and importance, International Environment Technology Centre, UNEP, and International Lake Environment Committee, Kusatsu

Rebelo, L.-M., McCartney, M.P. and Finlayson, C.M. (2011) 'The application of geospatial analyses to support an integrated study into the ecological character and sustainable use of Lake Chilwa', Journal of Great Lakes Research, vol 37, supplement 1, pp83-92

Richardson, S., Irvine, E., Froend, R., Boon, P., Barber, S. and Bonneville, B. (2011a) Australian groundwater-dependent ecosystems toolbox part 1: Assessment framework. Waterlines Report Series 69, National Water Commission, Canberra

Richardson, S., Irvine, E., Froend, R., Boon, P., Barber, S. and Bonneville, B. (2011b) Australian groundwater-dependent ecosystems toolbox part 2: Assessment tools. Waterlines Report Series 70, National Water Commission, Canberra

Richter, B.D., Baumgartner, J.V., Powell, J. and Braun, D.P. (1996) 'A method for assessing hydrologic alteration within ecosystems', Conservation Biology, vol 10, pp1163-1174 Richter, B.D., Warner, A.T., Meyer, J.L. and Lutz, K. (2006) 'A collaborative and adaptive process for developing environmental flow recommendations', River Research and Applications, vol 22, pp297-318

Roux, D.J., Nel, J.L., Ashton, P.J., Deacon, A.R., de Moor, F.C., Hardwick, D., Hill, L., Kleynhans, C.J., Maree, G.A., Moolman, J. and Scholes, R.J. (2008) 'Designing protected areas to conserve riverine biodiversity: Lessons from a hypothetical redesign of the Kruger National Park', Biological Conservation, vol 141, pp100-117

Solanes, M. and Gonzales-Villarreal, F. (1999) The Dublin Principles for water as reflected in a comparative assessment of institutional and legal arrangements for IWRM, Global Water Partnership, Stockholm 
Sommer, B. and Froend R.H. (2014) 'Alternative states of phreatophytic vegetation in a drying Mediterranean-type landscape', Journal of Vegetation Science, vol 25, pp1045-1055 Swirepik, J.L., Burns, I.C., Dyer, F.J., Neave, I.A., O’Brien, M.G., Pryde, G.M. and Thompson, T.M. (2015) 'Establishing environmental water requirements for the MurrayDarling Basin, Australia's largest developed water system', River Research and Applications, vol 32, pp1153-1165.

Tennant, D.L. (1976) 'Instream flow regimens for fish, wildlife, recreation and related environmental resources', Fisheries, vol 1, pp6-10

Tharme, R.E. (2003) 'A global perspective on environmental flow assessment: Emerging trends in the development and application of environmental flow methodologies for rivers', River Research and Applications, vol 19, pp397-441

Turpie, J.K. and Clark, B.M. (2007) The health status, conservation importance, and economic value of temperate South African estuaries and development of a regional conservation plan, Anchor Environmental Consultants AEC/07/01

Turpie, J.K., Sihlope, N., Carter, A., Maswime, T. and Hosking, S. (2007) Maximising the socio-economic benefits of estuaries through integrated planning and management: a rationale and protocol for incorporating and enhancing estuary values in planning and management. Appendix 1 in: Profiling estuary management in integrated development planning in South Africa with particular reference to the Eastern Cape Province, Water Research Commission publication 1485/1/07, Water Research Commission, Pretoria van Niekerk, L. and Turpie, J.K. (eds) (2012) South African national biodiversity assessment 2011: Technical report. Volume 3: Estuary Component, Council for Scientific and Industrial Research, Stellenbosch

Vörösmarty, C.J., McIntyre, P.B., Gessner, M.O., Dudgeon, D., Prusevich, A., Green, P., Glidden, S., Bunn, S.E., Sullivan, C.A., Liermann, C.R. and Davies, P.M. (2010) 'Global threats to human water security and river biodiversity', Nature, vol 467, pp555-561

Watson, J.E., Dudley, N., Segan, D.B., Hockings, M. (2014) 'The performance and potential of protected areas', Nature, vol 515, pp67-73

Wetzel, R. (2001) Limnology: Lake and river ecosystems,Elsevier/Academic Press, San Diego 
Winemiller, K.O., McIntyre, P.B., Castello, L., Fluet-Chouinard E,Giarrizzo, .T, Nam, S., Baird, I.G., Darwall, W., Lujan, N.K., Harrison, I.. 2016. 'Balancing hydropower and biodiversity in the Amazon, Congo and Mekong'. Science, vol 351, pp128-129 